\title{
Pengaruh durasi senam diabetes pada glukosa darah penderita diabetes mellitus tipe II
}

Effect of aerobic exercise duration on blood glucose type II diabetes

\author{
Weni Kurdanti', Tri Mei Khasana ${ }^{2}$ \\ ${ }^{1}$ Jurusan Gizi, Politeknik Kesehatan Kementerian Kesehatan Yogyakarta \\ ${ }^{2}$ Program Studi S1 Ilmu Gizi, Fakultas Ilmu Kesehatan Universitas Respati Yogyakarta
}

\begin{abstract}
Background: The management of DM focused on four pillars: education, nutrition therapy, physical exercise, and pharmacological interventions. In type 2 diabetes, physical activity functions primarily in controlling diabetes. Objective: This study aims to determine the effect of aerobic exercise duration on blood glucose levels. Method: This was quasi-experimental research with pre-post test design. A total of 24 respondents with type 2 diabetes were divided into two groups consisting of groups $A$ that received aerobic exercise with a duration of 30 minutes and group B received aerobic exercise with a duration of 60 minutes for 6 weeks and frequency of exercise 3 times each week. Statistical tests use paired t-tests and independent t-tests. Results: The mean post-test blood sugar level based on HbAlc measurements in group A was $7.92 \pm 1.56 \%$ while group B was $7.13 \pm 0.99 \%$. Mean pre-test post-test blood sugar levels in the two groups were significantly different $(p<0.05)$. Aerobic exercise for 6 weeks with a frequency of 3 times each week can reduce HbAlc by $-2.5 \pm 0.96 \%$ in group A while group B increased by $0.02 \pm 0.29 \%$. There is a significant difference in HbAlc before and after 6 weeks of aerobic exercise between two groups $(p=0.021)$. Conclusion: Aerobic exercise with a duration of 30 minutes for 6 weeks 3 times each week can reduce blood glucose (HbAlc) by $-2.5 \pm 0.96 \%$ while the group duration of aerobic exercise 60 minutes an increase of $0.02 \pm 0.29 \%$. There is a significant difference in HbAlc before and after 6 weeks of aerobic exercise between the two groups.
\end{abstract}

KEYWORDS: aerobic exercise; blood glucose; diabetes mellitus type II; HbAlc

\begin{abstract}
ABSTRAK
Latar belakang: Pilar utama pengelolaan DM yaitu perencanaan makan, latihan jasmani, obat berkhasiat hipoglikemik, dan penyuluhan. Pada DM tipe 2, aktivitas fisik berperan utama dalam pengendalian diabetes Tujuan: Penelitian ini bertujuan untuk mengetahui pengaruh perbedaan durasi senam diabetes terhadap kadar glukosa darah. Metode: Penelitian quasi eksperimen dengan pre test-post test design. Sebanyak 24 responden penderita DM tipe 2 penelitian ini dibagi menjadi dua kelompok perlakuan yaitu kelompok A mendapat perlakuan senam diabetes dengan durasi 30 menit dan kelompok B mendapat perlakuan senam diabetes dengan durasi 60 menit selama 6 minggu dan frekuensi senam 3 kali setiap minggu. Uji statistik menggunakan paired sample t-test dan independent $t$-test. Hasil: Rerata kadar gula darah post-test berdasarkan pengukuran HbAlc pada kelompok A sebesar 7,92 $\pm 1,56 \%$ sedangkan kelompok B sebesar 7,13 $\pm 0,99 \%$. Rerata kadar gula darah pre-test - post-test pada kedua kelompok berbeda signifikan $(\mathrm{p}<0,05)$. Perlakuan senam diabetes selama 6 minggu dengan frekuensi 3 kali setiap minggu dapat menurunkan kadar glukosa darah sebesar $-2,5 \pm 0,96 \%$ pada kelompok A sedangkan kelompok B mengalami peningkatan sebesar $0,02 \pm 0,29 \%$. Terdapat perbedaan yang signifikan selisih kadar HbA1c sebelum dan sesudah 6 minggu perlakuan antara kedua kelompok ( $\mathrm{p}=0,021)$. Simpulan: Perlakuan senam diabetes dengan durasi 30 menit selama 6 minggu sebanyak 3 kali setiap minggu dapat menurunkan kadar glukosa darah (HbAlc) sebesar $-2,5 \pm 0,96 \%$ sedangkan kelompok durasi senam 60 menit mengalami peningkatan sebesar $0,02 \pm 0,29 \%$. Terdapat perbedaan yang signifikan selisih kadar HbA1c sebelum dan sesudah 6 minggu perlakuan antara kedua kelompok.
\end{abstract}

KATA KUNCI: senam diabates; glukosa darah; diabetes mellitus tipe II; HbA1c

Korespondensi: Weni Kurdanti, Jurusan Gizi, Politeknik Kesehatan Kementerian Kesehatan Yogyakarta, Jl. Tatabumi No. 3, Banyuraden, Gamping, Sleman, Yogyakarta, Indonesia,e-mail: weni.kurdanti@gmail.com 


\section{PENDAHULUAN}

Diabetes mellitus (DM) merupakan salah satu penyakit degeneratif menahun yang tidak bisa disembuhkan, tetapi bisa dikendalikan. Penelitian epidemiologi menunjukkan adanya kecenderungan peningkatan angka insidensi dan prevalensi DM tipe 2 di berbagai penjuru dunia (1). Berdasarkan data riset kesehatan dasar (Riskesdas), pada tahun 2007 prevalensi nasional DM sebesar $1,1 \%$ yang meningkat menjadi $2,1 \%$ pada tahun 2013. Prevalensi DM yang tertinggi menurut diagnosis dokter ditemukan di Provinsi Daerah Istimewa Yogyakarta (DIY) (2,6\%) kemudian diikuti DKI Jakarta (2,5\%), Sulawesi Utara (2,4\%), dan Kalimantan Timur (2,3\%) (2). Sementara itu, berdasarkan data profil kesehatan Puskesmas Godean 1 tahun 2014 menunjukkan prevalensi DM tipe 2 pada pasien rawat jalan tahun 2013 untuk golongan umur lebih dari 70 tahun sebesar 10,25\%; pasien rawat jalan baru golongan umur lebih dari 70 tahun sebesar 4,97\%; dan pasien rawat jalan untuk semua golongan umur sebesar 2,66\% (3). Dengan demikian, harus dilakukan manajemen yang tepat untuk mengobati DM dan mencegah komplikasinya.

Pilar utama pengelolaan DM yaitu perencanaan makan, latihan jasmani, obat berkhasiat hipoglikemik, dan penyuluhan (4). Aktivitas fisik secara teratur memberikan banyak efek menguntungkan pada subjek yang sehat dan diabetes dari semua kelompok umur. Sebagian besar studi berbasis latihan aerobik juga menunjukkan efek yang menguntungkan pada DM tipe 2 (5). Pada DM tipe 1 (tergantung insulin), aktivitas fisik merupakan elemen mendasar bagi perkembangan fisik dan mental. Sementara pada DM tipe 2 (tidak tergantung insulin), aktivitas fisik berperan utama dalam pengendalian diabetes (6).

Diet dan berat badan yang tidak optimal, olahraga yang tidak teratur, serta kebiasaan merokok, telah terbukti sebagai pengganggu metabolisme (metabolic derangement). Gangguan ini semakin parah apabila terjadi komplikasi mikrovaskuler dan makrovaskuler pada penderita DM (7). Fungsi dan efisiensi metabolisme tubuh dapat ditingkatkan dengan aktivitas fisik rutin sesuai jenis olahraga yang dianjurkan untuk penderita DM yaitu olahraga aerobik salah satunya adalah senam diabetes (8). Namun demikian, latihan jasmani sering diabaikan oleh penderita DM. Penderita DM lebih fokus serta mengutamakan diet dan konsumsi obat antidiabetik, padahal penanganan diet yang teratur belum menjamin akan terkontrolnya kadar glukosa dalam darah jika tanpa latihan jasmani yang sesuai (9).

Fungsi senam DM yaitu meningkatkan kepekaan insulin pada otot-otot dan hati yang bisa menyebabkan penurunan dosis obat hipoglisemia oral atau insulin yang dibutuhkan penderita DM. Selain itu, profil lipid juga cenderung mengalami perbaikan. Aktivitas fisik yang kurang diduga merupakan faktor risiko langsung bagi perkembangan resistensi terhadap insulin pada DM tipe 2 (10). Hasil penelitian sebelumnya menunjukkan bahwa dari total 147 sampel penderita DM di Provinsi DIY, kurang dari 50\% sampel yang melakukan aktivitas fisik untuk mengelola penyakit DM (8). Menurut American Diabetes Association, pasien diabetes tipe 1 dan tipe 2 dianjurkan melakukan aktivitas aerobik intensitas sedang selama 30 hingga 60 menit (11). Penelitian terkait rekomendasi untuk jenis dan volume latihan fisik pada pasien DM sudah banyak dilakukan, tetapi belum banyak studi di Indonesia yang menunjukkan pengaruh intensitas atau durasi latihan fisik pada penurunan glukosa darah. Berdasarkan latar belakang tersebut, tujuan penelitian ini adalah untuk mengetahui pengaruh durasi senam diabetes terhadap penurunan glukosa darah penderita DM tipe 2 .

\section{BAHAN DAN METODE}

Jenis penelitian ini adalah eksperimen semu dengan rancangan pretest-postest design. Kelompok A diberikan aktivitas olah raga senam diabetes dengan durasi 30 menit dan kelompok B diberikan aktivitas olah raga senam diabetes dengan durasi 60 menit. Senam dilaksanakan tiga kali dalam seminggu selama enam minggu perlakuan pada kedua kelompok. Penelitian dilaksanakan di Puskesmas Godean I Kabupaten Sleman DIY pada bulan Maret - Agustus 2016. Berdasarkan perhitungan besar sampel, diperoleh jumlah sampel minimal untuk masingmasing kelompok sebesar 12 subjek.

Populasi pada penelitian ini adalah semua pasien diabetes mellitus di Puskesmas Godean I Kabupaten Sleman. Pengambilan sampel menggunakan teknik purposive sampling sesuai kriteria inklusi dan eksklusi penelitian kemudian pembagian sampel menjadi dua kelompok dilakukan secara acak atau random. Kriteria 
inklusi dalam penelitian ini adalah pasien DM tipe II yang berobat jalan di Puskesmas Godean I, dapat mengikuti aktivitas olahraga dari rekomendasi dokter Puskesmas Godean I, menggunakan obat hipoglikemik oral (OHO) dengan jenis yang sama, tidak ada komplikasi diabetic foot, dan bersedia mengikuti penilitian dengan mengisi informed consent. Kriteria eksklusi dalam penelitian ini adalah pasien DM tipe 2 yang menderita stroke, lemah jantung, kelumpuhan, penurunan kesadaran dan bedrest, pasien DM tipe 2 yang sedang hamil, dan terjadi komplikasi yang lebih berat setelah aktivitas olah raga.

Variabel bebas adalah durasi senam diabetes sedangkan variabel terikat yaitu kadar gula darah, serta variabel luar yaitu asupan makan, berat badan, dan indeks massa tubuh (IMT). Senam dilaksanakan tiga kali dalam seminggu dengan durasi senam 30 menit pada kelompok perlakuan A dan 60 menit pada kelompok perlakuan B selama 6 minggu perlakuan. Kadar glukosa darah pada penelitian ini diketahui berdasarkan nilai hemoglobin A1c (HbA1C) pada pemeriksaan kadar glukosa darah sewaktu (GDS) di laboratorium Puskesmas Godean I. Asupan makan adalah rerata jumlah energi, protein, lemak, dan karbohidrat yang berasal dari asupan makan yang dikonsumsi oleh responden yang dinilai menggunakan food recall 24 jam. Data berat badan diukur menggunakan timbangan digital dengan ketelitian $0,1 \mathrm{~kg}$ sedangkan tinggi badan menggunakan mikrotoa dengan ketelitiam $0,1 \mathrm{~cm}$. Data indeks massa tubuh $\left(\mathrm{kg} / \mathrm{m}^{2}\right)$ diperoleh dari hasil pengukuran berat badan (dalam kilogram) dibagi kuadrat tinggi badan (dalam meter). Data penelitian dikumpulkan oleh peneliti dan dibantu oleh enumerator mahasiswa jurusan gizi.

Pemeriksaan kadar glukosa darah dilakukan sebanyak dua kali yaitu di awal penelitian sebelum seluruh responden melakukan senam DM dan di akhir penelitian setelah responden melakukan senam DM selama enam minggu perlakuan. Uji bivariat untuk menganalisis pengaruh senam DM terhadap penurunan kadar gula darah dilakukan dengan paired sample t-test dengan nilai $\alpha=0,05$ dan tingkat kepercayaan 95\%. Selisih nilai pre-post antarkelompok dianalisis dengan uji independent t-test. Penelitian ini telah memperoleh persetujuan ethical clearance dari Komisi Etik Politeknik Kesehatan Kementerian Kesehatan Yogyakarta.

\section{HASIL}

Penelitian ini membagi responden menjadi dua kelompok perlakuan yaitu perlakuan senam diabetes dengan durasi 30 menit (kelompok A) dan senam diabetes dengan durasi 60 menit (kelompok B). Tabel 1 menunjukkan karakteristik subjek penelitian pada kedua kelompok perlakuan yaitu sebagian besar subjek penelitian berjenis kelamin perempuan, berusia 60-74 tahun, bekerja sebagai ibu rumah tangga (IRT), sudah menderita DM selama 1- 5 tahun, dan memiliki kebiasaan makan lebih dari atau sama dengan 3 kali dalam satu hari. Sementara itu, tingkat pendidikan subjek lebih bervariasi yaitu mayoritas pendidikan terakhir pada kelompok A adalah perguruan tinggi sedangkan pendidikan terakhir pada kelompok B adalah SMA. Hal ini menunjukkan

Tabel 1. Karakteristik subjek penelitian

\begin{tabular}{|c|c|c|c|c|}
\hline \multirow{3}{*}{ Variabel } & \multicolumn{4}{|c|}{ Kelompok } \\
\hline & \multicolumn{2}{|c|}{$A(n=12)$} & \multicolumn{2}{|c|}{$B(n=12)$} \\
\hline & n & $\%$ & $\mathbf{n}$ & $\%$ \\
\hline \multicolumn{5}{|l|}{ Jenis kelamin } \\
\hline Laki-laki & 3 & 25 & 4 & 33 \\
\hline Perempuan & 9 & 75 & 8 & 67 \\
\hline \multicolumn{5}{|l|}{ Umur (tahun) } \\
\hline $36-45$ & 1 & 8 & 1 & 8 \\
\hline $46-59$ & 5 & 42 & 3 & 25 \\
\hline $60-74$ & 6 & 50 & 8 & 67 \\
\hline \multicolumn{5}{|l|}{ Pendidikan } \\
\hline $\mathrm{SD}$ & 3 & 25 & 3 & 25 \\
\hline SMP & 2 & 17 & 1 & 8 \\
\hline SMA & 3 & 25 & 5 & 42 \\
\hline PT & 4 & 33 & 3 & 25 \\
\hline \multicolumn{5}{|l|}{ Pekerjaan } \\
\hline Ibu rumah tangga & 9 & 75 & 5 & 41 \\
\hline Wiraswasta & 1 & 8 & 3 & 25 \\
\hline Pegawai swasta & 0 & 0 & 2 & 17 \\
\hline Pensiunan & 2 & 17 & 2 & 17 \\
\hline \multicolumn{5}{|l|}{ Lama DM (tahun) } \\
\hline$<1$ & 1 & 8 & 1 & 8 \\
\hline $1-5$ & 6 & 50 & 5 & 42 \\
\hline $5-10$ & 2 & 17 & 3 & 25 \\
\hline$>10$ & 3 & 25 & 3 & 25 \\
\hline \multicolumn{5}{|l|}{ Kebiasaan makan } \\
\hline$<3$ kali & 5 & 42 & 5 & 42 \\
\hline 3 kali & 7 & 58 & 7 & 58 \\
\hline \multicolumn{5}{|c|}{ Konsumsi obat hipoglikemik oral } \\
\hline Ya & 12 & 100 & 11 & 92 \\
\hline Tidak & 0 & 0 & 1 & 8 \\
\hline
\end{tabular}


bahwa sebagian besar tingkat pendidikan subjek tergolong tinggi. Lebih lanjut, hampir seluruh subjek pada kedua kelompok mengkonsumsi obat untuk mengontrol kadar glukosa darah dan hanya satu orang pada kelompok B yang tidak mengkonsumsi OHO.

Berdasarkan rerata IMT, subjek pada kedua kelompok tergolong dalam status gizi overweight (IMT $\geq 23 \mathrm{~kg} / \mathrm{m}^{2}$ ). Hasil analisis pada Tabel 2 menunjukkan bahwa setelah perlakuan selama 6 minggu berupa senam diabetes dengan durasi 30 menit (kelompok A) dan 60 menit (kelompok B), dapat menurunkan berat badan dan IMT secara signifikan $(p=0,000)$. Lebih lanjut, Tabel 3 menunjukkan bahwa berdasarkan hasil recall 24 jam saat pre test, rerata persentase asupan makan terhadap

Tabel 2. Perbedaan rerata data antropometri antarkelompok

\begin{tabular}{lcccc}
\hline Antropometri & Min $^{4}$ & Maks $^{5}$ & Rerata \pm SD & p \\
\hline Kelompok A & & & & \\
Berat badan (kg) & & & & \\
$\quad$ Pre test & 43,80 & 85,60 & $58,05 \pm 10,46$ & 0,000 \\
$\quad$ Post test & 44,30 & 84,30 & $58,01 \pm 10,19$ & \\
IMT $^{2}\left(\mathrm{~kg} / \mathrm{m}^{2}\right)$ & & & & \\
$\quad$ Pre test & 20,50 & 29,30 & $24,24 \pm 2,51$ & 0,000 \\
$\quad$ Post test & 19,70 & 28,80 & $24,19 \pm 2.53$ & \\
Kelompok B & & & & \\
Berat badan $(\mathrm{kg})$ & & & & \\
$\quad$ Pre test & 41,20 & 101,0 & $63,87 \pm 17,41$ & 0,000 \\
$\quad$ Post test & 39,80 & 102,6 & $63,46 \pm 17,73$ & \\
IMT (kg $\left./ \mathrm{m}^{2}\right)$ & & & & \\
$\quad$ Pre test & 18,40 & 32,50 & $25,99 \pm 5,46$ & 0,000 \\
$\quad$ Post test & 17,60 & 32,46 & $25,91 \pm 5,42$ & \\
\hline
\end{tabular}

${ }^{1}$ Kelompok A=durasi senam 30 menit; ${ }^{2} \mathrm{IMT}=$ indeks massa tubuh; ${ }^{3}$ Kelompok B $=$ durasi senam 60 menit; ${ }^{4} \mathrm{Min}=$ minimal; ${ }^{5} \mathrm{Maks}=$ maksimal kebutuhan masing-masing subjek pada kedua kelompok masih tergolong kurang $(<80 \%)$ kecuali untuk rerata asupan lemak pada kelompok A yang sudah memenuhi sebesar 96,79 $\pm 38,31 \%$ kebutuhan bahkan pada kelompok B sudah melebihi kebutuhan mencapai 119,34 $\pm 48,88 \%$. Sementara itu, asupan makan subjek pada saat post test menunjukkan peningkatan pada kedua kelompok untuk semua asupan makan terutama rerata persentase asupan lemak yang menunjukkan peningkatan paling tinggi dan melebihi kebutuhan $(132,27 \pm 47,05 \%$ untuk kelompok A dan $154 \pm 42,66 \%$ untuk kelompok B). Namun, hasil analisis dengan paired sample t-test menunjukkan tidak adanya perbedaan yang signifikan $(\mathrm{p}>0,05)$ antara pre - post test untuk semua asupan makan (energi, protein, lemak, dan karbohidrat).

Hasil analisis pada Tabel 4 menunjukkan bahwa perlakuan senam diabetes selama 6 minggu dengan frekuensi 3 kali setiap minggu dapat menurunkan secara signifikan kadar glukosa darah subjek pada

Tabel 4. Perbedaan rerata kadar glukosa darah (HbA1c) antarkelompok

\begin{tabular}{lcccc}
\hline Kelompok & Min $^{3}$ & Maks $^{4}$ & $\begin{array}{c}\text { Rerata } \pm \text { SD } \\
(\%)\end{array}$ & $\mathbf{p}$ \\
\hline $\begin{array}{l}\text { Kelompok A } \\
\text { Pre test }\end{array}$ & 6,30 & 10,00 & $8,17 \pm 1,14$ & 0,002 \\
$\quad \begin{array}{l}\text { Post test } \\
\text { Kelompok B }\end{array}$ & 5,90 & 10,70 & $7,92 \pm 1,56$ & \\
$\quad$ Pre test & 5,80 & 8,80 & $7,12 \pm 0,95$ & 0,000 \\
$\quad$ Post test & 5,60 & 8,60 & $7,13 \pm 0,99$ & \\
\hline
\end{tabular}

${ }^{1}$ Kelompok $A=$ durasi senam 30 menit;

${ }^{2}$ Kelompok $\mathrm{B}=$ durasi senam 60 menit

${ }^{3} \mathrm{Min}=$ minimal; ${ }^{4} \mathrm{Maks}=$ maksimal

Tabel 3. Perbedaan rerata asupan makan terhadap kebutuhan (\%) antarkelompok

\begin{tabular}{lcccc}
\hline \multirow{2}{*}{ Kelompok } & \multicolumn{4}{c}{ Rerata \% asupan makan (Rerata \pm SD) } \\
\cline { 2 - 5 } & Energi & Protein & Lemak & Karbohidrat \\
\hline Kelompok A ${ }^{1}$ & & & & \\
Pre test & $70,20 \pm 18,59$ & $64,14 \pm 26,11$ & $96,79 \pm 38,31$ & $62,97 \pm 19,31$ \\
Post test & $103,07 \pm 36,95$ & $77,74 \pm 26,78$ & $132,27 \pm 47,05$ & $88,34 \pm 23,84$ \\
p & 0,490 & 0,259 & 0,784 & 0,235 \\
Kelompok B & & & & \\
Pre test & $73,32 \pm 18,66$ & $70,07 \pm 20,54$ & $119,34 \pm 48,88$ & $61,26 \pm 21,47$ \\
Post test & $97,83 \pm 16,48$ & $90,96 \pm 28,89$ & $154,00 \pm 42,66$ & $87,23 \pm 17,53$ \\
p & 0,276 & 0,468 & 0,435 & 0,278 \\
\hline
\end{tabular}

${ }^{1}$ Kelompok A=durasi senam 30 menit; ${ }^{2}$ Kelompok B=durasi senam 60 menit 
kelompok durasi senam 30 menit $(\mathrm{p}=0,002)$. Namun, sebaliknya dengan kelompok durasi senam 60 menit yang menunjukkan peningkatan signifikan kadar glukosa darah $(\mathrm{p}=0,000)$ meskipun nilainya sangat kecil. Lebih lanjut, diketahui bahwa terjadi penurunan glukosa darah sebesar -2,5 $\pm 0,96 \mathrm{mg} / \mathrm{dL}$ pada kelompok A sedangkan kelompok B mengalami peningkatan yang kecil yaitu sebesar 0,02 $\pm 0,29 \mathrm{mg} / \mathrm{dL}$, dan perbedaan selisih antara kedua kelompok ini signifikan $(p=0,021)$.

\section{BAHASAN}

Hasil analisis menunjukkan bahwa sebagian besar subjek penelitian pada kedua kelompok berjenis kelamin perempuan dan mayoritas berusia 60-74 tahun kemudian diikuti usia 46-59 tahun. Rentang usia subjek penelitian ini sesuai dengan teori yang menyebutkan bahwa usia merupakan faktor risiko untuk terjadinya penyakit DM. Kurva kejadian DM tipe 2 mencapai puncaknya pada usia setelah 40 tahun, hal ini karena kelompok usia di atas 40 tahun berisiko lebih tinggi terkena DM akibat menurunnya toleransi glukosa yang berhubungan dengan berkurangnya sensitivitas sel perifer terhadap efek insulin (12). Pada usia 40-70 tahun, DM lebih banyak terjadi pada perempuan, tetapi pada umur yang lebih muda frekuensi DM lebih besar pada laki-laki. Hal ini juga dipicu oleh adanya persentase timbunan lemak tubuh pada perempuan lebih besar dibandingkan dengan lakilaki yang dapat menurunkan sensitivitas terhadap kerja insulin pada otot dan hati (13).

Temuan utama dari penelitian ini adalah adanya penurunan rerata kadar glukosa darah berdasarkan pengukuran $\mathrm{HbA} 1 \mathrm{c}$ pada kelompok durasi senam diabetes 30 menit $(-2,5 \pm 0,96 \%)$ dan sebaliknya ditemukan peningkatan kadar HbA1c $(0,02 \pm 0,29 \%)$ pada kelompok durasi senam diabetes 60 menit. Selisih kadar HbA1c sebelum dan sesudah 6 minggu perlakuan tersebut menunjukkan perbedaan yang signifikan antara kedua kelompok $(p=0,021)$. Hasil penelitian ini menunjukkan bahwa durasi senam selama 30 menit dengan frekuensi 3 kali setiap minggu lebih efektif untuk menurunkan kadar glukosa darah. Namun, hasil studi menyebutkan bahwa intensitas latihan fisik bukanlah prediktor independen untuk pengurangan salah satu dari parameter faktor risiko kardiovaskular yang dapat dimodifikasi pada penderita DM tipe 2. Studi di Italia tersebut membandingkan latihan aerobik dan kekuatan otot insensitas moderat-tinggi (HI) dibandingkan intensitas rendah-moderat (LI) pada subjek DM tipe 2. Hasil studi tersebut menemukan bahwa latihan fisik HI hanya menghasilkan sedikit peningkatan klinis dibandingkan dengan pelatihan LI, meskipun secara statistik signifikan, yaitu pada parameter HbA1c, trigliserida, dan kolesterol total tetapi tidak dalam faktor risiko kardiovaskular yang lain dan skor risiko penyakit jantung koroner (PJK). Studi tersebut juga menyebutkan bahwa penderita DM tipe 2 dengan kondisi kebugaran rendah atau berperilaku sedentari, latihan fisik LI kurang lebih sama efektifnya dengan latihan HI dalam mengurangi beban dan faktor risiko kardiovaskular yang dapat dimodifikasi. Dengan demikian, rekomendasi untuk tujuan praktis adalah subjek sebaiknya lebih memperhatikan volume dan jenis latihan dibandingkan intensitas atau durasi ketika latihan diterapkan sebagai bentuk terapi pada subjek dengan kondisi tersebut (14).

Menurut laporan, mayoritas orang mengumpulkan waktu lebih dari atau sama dengan 30 menit aktivitas fisik dengan intensitas sedang pada sebagian besar hari dalam seminggu. Namun, sebagian besar uji klinis mengevaluasi intervensi olahraga pada orang dengan DM tipe 2 lebih banyak yang menggunakan frekuensi tiga kali per minggu dan banyak orang merasa lebih mudah untuk menjadwalkan aktivitas dengan frekuensi lebih sedikit dan durasi lebih lama daripada frekuensi lima atau lebih dalam satu minggu dengan durasi pendek. Efek dari satu latihan aerobik pada sensitivitas insulin berlangsung 24-72 jam tergantung pada durasi dan intensitas aktivitas. Hal ini karena durasi peningkatan sensitivitas insulin umumnya tidak lebih dari 72 jam, sehingga rekomendasi untuk penderita DM adalah tidak boleh lebih dari 2 hari berturut-turut tanpa aktivitas fisik aerobik (15). Jika tujuan aktivitas fisik adalah untuk meningkatkan kontrol glikemik, membantu menjaga berat badan, dan mengurangi risiko kardiovaskuler, maka direkomendasikan untuk setidaknya melakukan aktivitas fisik aerobik intensitas sedang selama 150 menit/minggu (40-60\% dari VO2 maks atau 50-70\% dari denyut jantung maksimum) dan atau setidaknya 90 menit/minggu latihan aerobik yang kuat ( $>60 \%$ dari VO2 maks atau $>70 \%$ dari 
denyut jantung maksimum) (15). Sejalan dengan ulasan yang menyatakan bahwa individu dianjurkan untuk melakukan aktivitas fisik 30 menit pada sebagian besar hari dalam satu minggu. Hal ini terkait dengan epidemi DM tipe 2 yang dikaitkan dengan penurunan tingkat aktivitas dan meningkatnya prevalensi obesitas. Oleh karena itu, olahraga merupakan komponen vital dari pencegahan serta penatalaksanaan DM tipe 2 yang menjadi prioritas utama untuk diimplementasikan (11).

Lebih lanjut, hasil penelitian ini menunjukkan bahwa rerata kadar HbAlc pre-post test pada kelompok durasi senam diabetes 30 menit $(8,17 \pm 1,14 \%$ menjadi $7,92 \pm 1,56 \%)$ lebih tinggi jika dibandingkan dengan kelompok durasi senam diabetes 60 menit $(7,12 \pm 0,95 \%$ menjadi $7,13 \pm 0,99 \%$ ). Hal ini mungkin berpengaruh terhadap penurunan kadar glukosa yang lebih signifikan pada kelompok durasi senam diabetes 30 menit. Selain itu, kemungkinan lain yaitu perlakuan yang hanya diberikan selama 6 minggu sehingga durasi intervensi belum cukup untuk dapat menunjukkan kontrol kadar glukosa darah. Pengukuran HbA1c merupakan indikator jangka panjang kontrol glukosa darah. Pemeriksaan HbAlc ini menggambarkan rerata gula darah selama 2 sampai 3 bulan terakhir sehingga tidak dapat digunakan untuk memantau kadar glukosa darah per hari atau tes rutin gula darah. Pemeriksaan HbAlc merupakan pemeriksaan standar untuk menilai status glikemik jangka panjang dan efektif pada semua tipe penyandang DM (16). Hasil penelitian lain membuktikan bahwa kadar HbAlc menunjukkan nilai rerata glukosa darah selama 3 bulan dan penurunan setiap 1\% HbA1c dihubungkan dengan penurunan insiden penyakit kardiovaskular sebesar $15 \%-20 \%$ dan penurunan komplikasi penyakit mikrovaskular sebesar 37\% (17).

Faktor lain yang juga berpengaruh terhadap peningkatan glukosa darah pada kelompok durasi senam diabetes 60 menit adalah sebagian besar $(67 \%)$ usia responden berada pada rentang 60-74 tahun. Fenomena tersebut sesuai dengan teori bahwa kestabilan kadar gula darah akan semakin sulit untuk dipertahankan dalam kadar normal seiring dengan peningkatan usia (18). Hasil studi di Swiss menyatakan bahwa pada usia lebih dari 55 tahun, fungsi tubuh secara fisiologis menurun akibat terjadi penurunan sekresi atau resistensi insulin sehingga kemampuan fungsi tubuh terhadap pengendalian glukosa darah yang tinggi kurang optimal. Penelitian di Amerika Serikat pada responden yang berusia lebih dari 55 tahun, hanya ditemukan $12 \%$ responden dengan kadar gula terkendali. Pada lansia, terjadi pengecilan pembuluh darah sehingga dapat menyebabkan sirkulasi darah menurun dan proses perbaikan atau pengendalian kadar gula darah optimal lebih sulit (19).

Lebih lanjut, perlakuan durasi senam diabetes 60 menit pada penelitian ini belum menghasilkan efek penurunan kadar glukosa darah. Justru sebaliknya, kadar gula darah subjek mengalami kenaikan, hal ini kemungkinan didukung oleh pola diet yang kurang baik pada subjek di kelompok tersebut. Berdasarkan hasil recall diketahui bahwa rerata persentase asupan lemak kelompok durasi senam diabetes 60 menit pada pre-test maupun post-test sudah melebihi kebutuhan terutama pada post-test yang mencapai $154 \pm 42,66 \%$ melebihi kebutuhan. Sejalan dengan studi sebelumnya bahwa senam diabetes rutin 3 kali dalam 1 minggu dengan durasi 15-40 menit dapat menurunkan kadar gula darah. Namun, 10 dari 47 responden mengalami kenaikan kadar gula darah karena tidak mengontrol pola makan atau diet (20). Hal ini terkait dengan peranan penting asupan lemak dalam mempertahankan sensitivitas insulin. Asupan lemak yang tinggi akan menurunkan kadar adiponektin dalam darah yang bertugas untuk mengontrol sensitivitas insulin (21). Hal ini juga sesuai dengan teori yang menyatakan bahwa pola diet turut serta dalam mengendalikan kadar gula darah. Semakin buruk pola diet seorang penderita diabetes, maka tingkat kadar gula darah juga akan semakin meningkat. Pola diet yang berlebihan menyebabkan gangguan metabolisme zat-zat makanan, baik berupa karbohidrat, protein, dan lemak. Zat makanan tersebut tidak dapat dipecah menjadi sari makanan sehingga tidak terserap oleh usus halus dan menyebabkan terjadinya penumpukan zat makanan di dalam tubuh yang memicu terjadinya peningkatan kadar gula darah (22).

Hasil penelitian juga menunjukkan penurunan yang signifikan rerata berat badan dan nilai IMT pada kedua kelompok. Meskipun penurunan berat badan prepost test menunjukkan hasil yang signifikan, rerata nilai penurunannya kecil yaitu sebesar $0,04 \mathrm{~kg}$ pada kelompok durasi senam 30 menit dan sebesar $0,41 \mathrm{~kg}$ pada kelompok durasi senam 60 menit. Studi meta-analisis menunjukkan 
bahwa hasil program latihan terstruktur secara statistik dan klinik memberikan pengaruh bermanfaat yang signifikan terhadap kontrol glukosa darah tetapi tidak ada perubahan signifikan pada berat badan (rerata penurunan $\mathrm{BB}=0,54 \mathrm{~kg}$ ) antara kelompok latihan dibandingkan dengan kelompok kontrol (23). Latihan jasmani pada penderita DM dapat menyebabkan terjadinya peningkatan pemakaian glukosa oleh otot yang aktif sehingga secara langsung latihan jasmani dapat menyebabkan penurunan kadar glukosa darah. Selain itu, penurunan berat badan sebesar 5-10\% disertai dengan latihan jasmani teratur mampu mengurangi risiko timbulnya DM tipe II sebesar 58\% sedangkan penggunaan obat (seperti metformin, tiazolidindion, acarbose) hanya mampu menurunkan risiko sebesar $31 \%$ (8).

Pengelolaan DM dapat dilakukan secara nonfarmakologis, salah satunya adalah dengan perencanaan makan yang sangat ditentukan oleh jumlah, jenis, dan waktu makan serta aktivitas fisik rutin yang ditentukan oleh jenis, frekuensi, intensitas, dan durasi latihan. Tinjauan sistematis dan meta-analisis menunjukkan bahwa aktivitas olahraga terstruktur, baik aerobik, kekuatan otot, atau kombinasi keduanya berhubungan dengan penurunan kadar HbA1c pada pasien dengan DM tipe 2, terutama jika durasi olahraga lebih dari 150 menit per minggu dan jika dikombinasikan dengan saran diet (24). Asupan diet memiliki peranan yang sangat penting dalam pemeliharaan gula darah. Asupan diet yang berupa karbohidrat berlebih, asupan lemak yang tidak dibatasi, dan asupan rendah serat merupakan penyebab pengendalian gula darah yang buruk. Penelitian terkini menunjukkan adanya hubungan sinergi antara pola diet dan HbA1c. Semakin baik kualitas diet maka semakin baik pula HbA1c pasien DM tipe 2 (25).

Hampir seluruh subjek pada kedua kelompok mengkonsumsi obat untuk mengontrol kadar glukosa darah. Penggunaan obat hipoglikemik oral (OHO) yang diikuti dengan latihan jasmani akan menimbulkan efek sinergi terhadap peningkatan sensitivitas insulin. Penggunaan OHO dengan dosis yang sama akan menimbulkan efek yang berbeda terhadap kadar glukosa darah jika disertai dengan latihan jasmani. Hasil penelitian juga menyebutkan bahwa latihan jasmani dapat menurunkan jumlah OHO yang dibutuhkan (26).
Kesimpulan dari hasil penelitian ini, meskipun durasi senam 30 menit signifikan dalam menurunkan kadar glukosa darah dibandingkan durasi senam 60 menit. Namun, senam diabetes dapat berperan dalam pengaturan kadar glukosa darah jika dilakukan sesuai prinsip senam diabetes yaitu memenuhi standar frekuensi, intensitas, durasi, dan jenis senam (27). Prinsip senam diabetes untuk dapat mencapai hasil yang optimal yaitu latihan jasmani harus dilakukan secara teratur 3-5 kali setiap minggu dan tidak lebih dari 2 hari berurutan tanpa latihan (28). Selain itu, penderita DM juga perlu mengupayakan gaya hidup sehat yaitu dengan mengatur pola makan yang sehat dan tidak berlebihan. Hal ini terkait dengan hasil penelitian ini bahwa subjek pada kelompok durasi senam diabetes 60 menit mengalami peningkatan kadar glukosa darah pada akhir penelitian kemungkinan karena asupan lemak yang melebihi kebutuhan sehingga dapat mengganggu sensitivitas insulin.

\section{SIMPULAN DAN SARAN}

Perlakuan senam diabetes dengan durasi 30 menit selama 6 minggu sebanyak 3 kali setiap minggu dapat menurunkan kadar glukosa darah (HbA1c) sebesar $-2,5 \pm 0,96 \%$ sedangkan kelompok durasi senam 60 menit mengalami peningkatan sebesar $0,02 \pm 0,29 \%$. Terdapat perbedaan yang signifikan selisih kadar $\mathrm{HbA} 1 \mathrm{c}$ sebelum dan sesudah 6 minggu perlakuan antara kedua kelompok. Pelayanan kesehatan masyarakat terutama puskesmas sebaiknya memberikan fasilitas bagi penderita DM untuk dapat mengikuti senam diabetes dengan durasi 30 menit secara rutin sebanyak 3 kali setiap minggu. Perlu juga diberikan edukasi atau konseling tentang pentingnya menjaga asupan makan atau terapi diet dan aktivitas fisik di samping terapi medis.

\section{Pernyataan konflik kepentingan}

Penulis menyatakan tidak ada konflik kepentingan dengan pihak-pihak yang terkait dalam penelitian ini.

\section{RUJUKAN}

1. Perkumpulan Endokrinologi Indonesia. Konsensus pengelolaan dan pencegahan diabetes mellitus tipe 2 di Indonesia. Jakarta: PB. PERKENI; 2011. 
2. Kementerian Kesehatan RI. Riset kesehatan dasar 2013. Jakarta: Badan Penelitian dan Pengembangan Kesehatan Depkes RI; 2014.

3. Puskesmas Godean 1. Profil Kesehatan Puskesmas Godean 1. Yogyakarta: Puskesmas Godean 1; 2014.

4. Soegondo S, Soewondo P, Subekti I. Penatalaksanaan diabetes melitus terpadu. Jakarta: Balai Penerbit FKUI; 2009.

5. Thent ZC, Das S, Henry LJ. Role of exercise in the management of diabetes mellitus: the global scenario. PLoS One. 2013;8(11):e80436. doi: 10.1371/journal. pone. 0080436 .

6. Kourtoglou GI. Insulin therapy and exercise. Diabetes Res Clin Pract. 2011 Aug;93 Suppl 1:S73-7. doi: 10.1016/ S0168-8227(11)70017-1.

7. Arisman. Obesitas, diabetes mellitus, dan dislipidemia. Jakarta: ECG; 2011.

8. Ilyas EI. Olahraga bagi Diabetesi. Dalam: Soegondo S, Soewondo P, Subekti I, editor. Penatalaksaan diabetes melitus terpadu bagi dokter maupun edukator diabetes. Jakarta: Fakultas Kedokteran Universitas Indonesia; 2011.

9. Sinaga J, Hondro E. Pengaruh senam diabetes mellitus terhadap kadar glukosa darah pada penderita diabetes mellitus tipe 2 di wilayah kerja Puskesmas Darusalalm Medan 2011. Jurnal Mutiara Ners [series online] 2012 [cited September 2016];1(7):1-7. Available online: URL: http://lppm.sari-mutiara.ac.id/artikel-209.html

10. Mc.Wright B. Panduan bagi penderita diabetes. Jakarta: Prestasi Pustaka; 2008.

11. American Diabetes Association. Diabetes mellitus and exercise. Diabetes Care 2002; 25(suppl 1): s64-s64. doi: 10.2337/diacare.25.2007.S64

12. Haznam. Endokrinologi. Bandung: Angkasa Offset; 1991.

13. Ferrannini E. Insulin resistance versus insulin deficiency in non-insulin-dependent diabetes mellitus: problems and prospects. Endocr Rev 1998;19(4):477-90. doi: 10.1210/ edrv.19.4.0336

14. Balducci S, Zanuso S, Cardelli P, Salvi L, Bazuro A, Italian Diabetes Exercise Study (IDES) Investigators, et al. Effect of high- versus low-intensity supervised aerobic and resistance training on modifiable cardiovascular risk factors in type 2 diabetes; the Italian Diabetes and Exercise Study (IDES). PLoS One. 2012;7(11):e49297. doi: 10.1371/ journal.pone.0049297.

15. Sigal RJ, Kenny GP, Wasserman DH, Castaneda-Sceppa C, White RD. Physical activity/exercise and type 2 diabetes: a consensus statement from the American Diabetes Association. Diabetes Care. 2006;29(6):1433-8. doi: 10.2337/dc06-9910.

16. Powers AC. Diabetes mellitus. In: Longo DL, Faucy AS, Kasper DL, Hauser SL, Jameson JL, Loscalzo J, editors.
Harrison's internal medicine (18th ed). United States of America: The McGraw-Hill Company; 2012.

17. Church ST, Balir SN, Cocreham S, Johannsen N, Johnson $\mathrm{W}$, Earnest CP, et al. Effects of aerobic and resistance training on hemoglobin A1c levels in patients with type 2 diabetes: a randomized controlled trial. JAMA 2010;304(20):2253-62. doi: 10.1001/jama.2010.1710.

18. Tandra H. Diabetes: tanya jawab lengkap dengan ahlinya. Jakarta: PT Gramedia Pustaka Utama; 2008.

19. Jelantik IMG, Haryati E. Hubungan faktor risiko umur, jenis kelamin, kegemukan dan hipertensi dengan kejadian diabetes mellitus tipe II di wilayah kerja Puskesmas Mataram. Media Bina Ilmiah 2014;8(1):39-44.

20. Sanjaya AF, Huda M. Pengaruh senam diabetes terhadap penurunan kadar gula darah pada penderita diabetes mellitus di wilayah kerja Puskesmas Peterongan Jombang. Jurnal Ilmiah Keperawatan (Scientific Journal of Nursing) [series online] 2016 [cited September 2016];2(1):6-14. Available online: URL: http://journal.stikespemkabjombang.ac.id/ index.php/jikep/article/view/12

21. Xu A, Wang Y, Lam KSL. Adiponektin. Dalam: Fantuzzi G, Mazzone T. Nutrition \& helath: adipose tissue and adipokines in health and disease. New Jersey: Humana Press; 2007.

22. Sari RN. Diabetes Melitus. Yogyakarta: Nuha Medika; 2012.

23. Boulé NG, Haddad E, Kenny GP, Wells GA, Sigal RJ. Effects of exercise on glycemic control and body mass in type 2 diabetes mellitus: a meta-analysis of controlled clinical trialse. JAMA 2001;286(10):1218-27. doi: 10.1001/jama.286.10.1218.

24. Umpierre D, Ribeiro PA, Kramer CK, Leitão CB, Zucatti AT, Schaan BD, et al. Physical activity advice only or structured exercise training and association with $\mathrm{HbAlc}$ levels in type 2 diabetes: a systematic review and metaanalysis. JAMA. 2011;305(17):1790-9. doi: 10.1001/ jama.2011.576.

25. Nutall FQ, Gannon MC. Dietary protein and the blood glucose concentration. Diabetes Care 2013;62(5):1371-2. doi: $10.2337 / \mathrm{db} 12-1829$.

26. Erlina L., 2010. Pengaruh senam diabetes terhadap kadar glukosa darah pasien DM tipe 2 di RSU Unit Swadana Daerah Kabupaten Sumedang. Available online: http://stikesayani.ac.id/publikasi/e-journal/ filesx/2010/201008/201008-001.pdf

27. Santoso M. Senam diabetes seri 3. Jakarta: Yayasan Diabetes Indonesia; 2006.

28. American Diabetes Association. Diagnosis and classification of dibetes mellitus. Dalam: Buku ajar ilmu penyakit dalam edisi III jilid IV. Jakarta: Pusat Penerbitan Ilmu Penyakit Dalam Fakultas Kedokteran UI; 2014. 